Recenzje 



\section{IZABELA LERACZYK}

\section{IUS BELLI ET PACIS W REPUBLIKAŃSKIM RZYMIE WydAWNictWo KUL, LUBLIN 2018, ss. 255}

W potocznym wyobrażeniu i w popkulturze Rzym, jako jedno ze starożytnych imperiów, kojarzony jest głównie z okresem cesarstwa, zaś jego potęga wiązana jest najczęściej z bitną, doskonale wyszkoloną i dowodzoną armią, której podboje pozwoliły na stworzenie mocarstwa sięgającego od Wielkiej Brytanii do Egiptu i wybrzeży Afryki nad Morzem Śródziemnym oraz od Półwyspu Iberyjskiego do terytorium Azji Mniejszej. Rozkwit Imperium Rzymskiego nie byłby jednak możliwy bez opanowania Italii i pokonania zagorzałych przeciwników Rzymu - Kartaginy i Macedonii, co nastąpiło jeszcze w okresie republiki. Również w republikańskim Rzymie doszło do istotnych zmian w strukturze, wyposażeniu i funkcjonowaniu legionów (przede wszystkim dzięki reformie wojskowej konsula Gajusza Mariusza u schyłku II w. przed Chr.), co w rezultacie pozwoliło na wprowadzenie armii zawodowej ${ }^{1}$.

Wśród historyków zajmujących się dziejami starożytnych cywilizacji występuje oczywiście dużo większa świadomość znaczenia osiągnięć republikańskiego Rzymu dla rozwoju Imperium Romanum, a zagadnienia dotyczące Republiki Rzymskiej są przez nich nie rzadziej poruszane niż kwestie odnoszące się do Cesarstwa Rzymskiego. Jeśli jednak chodzi o temat podbojów rzymskich, historycy zazwyczaj skupiają się na ich aspektach politycznych i militarnych, ewentualnie społecznych - nieczęsto natomiast odwołują się do normatywnego wymiaru wojen prowadzonych przez Rzym. Lukę w tym zakresie niewątpliwie wypełnia publikacja autorstwa I. Leraczyk, zatytułowana "Ius belli et pacis” w republikańskim Rzymie. Autorka trafnie zauważa, że istotnymi (jeśli nie dominującymi) na przestrzeni wieków elementami polityki zagranicznej państw były

\footnotetext{
1 Szerzej na ten temat zob. m.in.: B.T. Carey, J.B. Allfree, J. Cairns, Wojny starożytnego świata. Techniki walki, Warszawa 2008, s. 158-163; P. Connolly, Historia armii rzymskiej, Wrocław 1992, s. 26-27; S.E. Stout, Training Soldiers for the Roman Legion, The Classical Journal 1921, t. 16, nr 7, s. 425-426.
} 
wojny - a ściślej ich wypowiadanie i prowadzenie - oraz sojusze. Dostrzegając zatem źródło sukcesu Rzymian w umiejętnym połączeniu supremacji militarnej z działaniami dyplomatycznymi, autorka podjęła się gruntownej analizy zagadnień dotyczących wypowiadania wojen i ich kończenia (poprzez zawieranie traktatów bądź w drodze kapitulacji), a także zawierania przymierzy. Za okres badawczy przyjęła zaś okres istnienia ustroju republikańskiego (lata 509-27 przed Chr.).

To pierwsza taka monografia wydana w Polsce, w sposób niezwykle szczegółowy traktująca o prawie wojny i prawie pokoju w Republice Rzymskiej, postrzeganych z perspektywy współczesnych definicji, zasad i teorii prawa międzynarodowego publicznego. Autorka przyjmuje bowiem - powołując się w tym względzie na wielu przedstawicieli doktryny prawa międzynarodowego - iż w czasach antycznych istniały regulacje międzynarodowoprawne, ponieważ ówczesne państwa zawierały między sobą różnorodne porozumienia i traktaty, przy czym ich wzajemne relacje regulowane były ponadto przez zasady o charakterze zwyczajowym. Jednocześnie wskazuje na swoisty „prymitywizm” norm międzynarodowoprawnych oraz ich silne powiązanie $z$ normami sakralnymi, podkreślając jednak, że ów prymitywizm w czasach republikańskiego Rzymu wynikał ze zwyczajowej natury norm prawnych - jest to zatem określenie dyskusyjne. Autorka zwraca ponadto uwagę na wieloznaczność pojęcia ius gentium (prawo narodów), niegdyś przez prawników uznawanego za synonim prawa międzynarodowego, lecz w literaturze romanistycznej używanego zwykle w odniesieniu do norm prawa prywatnego. Autorka przekonuje jednak, że ius gentium regulowało również kwestie uznawane za domenę prawa międzynarodowego publicznego, takie jak dopuszczalność wojen, nietykalność posłów czy prawa i obowiązki wynikające z zawarcia traktatów, a stanowiące przedmiot jej zainteresowania prawo wojny (ius belli) i prawo pokoju (ius pacis) należą właśnie do ius gentium.

Specyfika przyjętego przez autorkę celu badań wymagała równie specyficznego podejścia do analizowanego materiału źródłowego. Rzym zawierał przymierza, wysyłał posłów bądź wypowiadał wojny zgodnie $\mathrm{z}$ przyjętymi procedurami tylko $\mathrm{w}$ przypadku relacji $\mathrm{z}$ podmiotami zewnętrznymi godnymi - według jego mniemania - równego traktowania. W myśl prawa międzynarodowego, były to podmioty suwerenne. Badania wymagały więc sięgnięcia nie tylko po źródła prawa rzymskiego (zarówno publicznego, jak i prywatnego), lecz także po źródła literackie, zawierające opisy postępowania Rzymian z innymi ludami, czyli ukształtowane 
w dobie republikańskiej zwyczaje będące głównym źródłem norm międzynarodowoprawnych w tym okresie. Dopiero analiza obu rodzajów źródeł - prawnych i pozaprawnych - pozwoliła autorce przedstawić poszczególne instytucje prawa międzynarodowego stosowane przez Rzymian.

Omówienie prawa wojny i pokoju w republikańskim Rzymie I. Leraczyk słusznie poprzedziła gruntowną prezentacją charakteru źródeł prawa międzynarodowego publicznego obowiązujących w badanym okresie. W rozdzialeI, poza wspomnianymi już rozważaniami na temat terminu ius gentium, znajdują się uwagi dotyczące źródeł prawa w znaczeniu materialnym, formalnym i poznawczym. Ubogi materiał źródłowy oraz nieprecyzyjność i wieloznaczność pojęć używanych w celu określenia rzymskich instytucji prawnych wpłynęły na decyzję autorki o sięgnięciu do terminologii współczesnego prawa międzynarodowego, co bez wątpienia znacznie ułatwiło zrozumienie regulacji obowiązujących w starożytnym Rzymie. Autorka wyjaśnia zatem, jak w świetle dorobku prawnego badanego okresu rozumieć należy traktaty międzynarodowe i jak kształtował się zwyczaj międzynarodowy - w przypadku obu tych formalnych źródeł prawa międzynarodowego podając konkretne przykłady ich zastosowania. Interesujące są zwłaszcza uwagi na temat elementów prawa międzynarodowego w polityce zagranicznej Rzymu - działania podejmowane przez senat, konsulów czy trybunów wojskowych można bowiem uznać za przejaw praktyki państwa rzymskiego. Z kolei za przykład poglądów nauki prawa międzynarodowego autorka podała traktaty filozoficzne Cycerona. Wyjaśniła również, jaką rolę i znaczenie $\mathrm{w}$ republikańskim Rzymie pełniło tzw. prawo fecjałów (ius fetiale). Ceremonie dotyczące zawierania przymierzy czy wypowiadania wojen cechowały się znaczącym formalizmem, a za prawidłowe przestrzeganie stosownych rytuałów odpowiedzialne było kolegium kapłańskie fecjałów. Tym samym, normy sakralne, stanowiące ius fetiale, miały istotny wpływ na normy stosowane w stosunkach z innymi ludami - przykładowo: bez zgody fecjałów nikt w Rzymie, niezależnie od pozycji, nie mógł rozpocząć kampanii wojennej.

Problematyka prawa wojny w republikańskim Rzymie została dogłębnie omówiona w rozdziale II recenzowanej monografii. Jako punkt wyjścia dla tej analizy, I. Leraczyk przyjęła obowiązujący do dziś w prawie międzynarodowym podział na "prawo do prowadzenia wojny” (ius ad bellum) $\mathrm{i}$ "prawo stosowane w czasie wojny" (ius in bello), dowodząc, iż zalążki tego podziału odnaleźć można właśnie $\mathrm{w}$ historii wojen prowadzonych przez Rzym. Wojna była bowiem dla Rzymian stanem faktycznym, który 
rodził określone skutki prawne. W świetle badań autorki, Rzymianie mieli jednak inne podejście do obu wspomnianych instytucji. Prawo do prowadzenia wojny posiadał jedynie ten, kto kierował się słuszną przesłanką wypowiedzenia wojny (iusta causa belli), wówczas wojna mogła uchodzić za sprawiedliwą (bellum iustum). Spełniony musiał być również warunek formalny, tzn. wszczęcie wojny zgodnie z procedurą sakralno-prawną. Autorka w przystępny sposób przybliża wszelkie aspekty dotyczące wypowiadania wojen, począwszy od samej koncepcji wojny sprawiedliwej, poprzez przesłanki uzasadniające wszczęcie wojny, na ceremonii wypowiadania wojen (i roli, jaką odgrywało w niej ius fetiale) skończywszy. Omawiane aspekty „prawa do wojny” ilustruje licznymi przykładami z historii Republiki, które pomagają w zrozumieniu zwłaszcza kwestii proceduralnych, ściśle przestrzeganych przez ówczesnych Rzymian.

O ile jednak ius ad bellum traktowano poważnie i uświęcano normami religijnymi, ius in bello w praktyce właściwie nie istniało, a przynajmniej jak podkreśla I. Leraczyk - niewiele wiadomo na temat regulacji prawnych dotyczących postępowania w trakcie toczących się już konfliktów. Niewątpliwie wskutek rozpoczęcia wojny, wrogami (hostes) dla Rzymian stawały się wszystkie osoby należące do strony przeciwnej, a więc nie tylko żołnierze, lecz także ludność cywilna (obywatele i niewolnicy). Tym samym, każda osoba będąca wrogiem mogła stać się celem ataku bądź zostać uprowadzona, co mogło być początkiem jej niewoli, zaś majątek nieprzyjaciół był wydawany na łup żołnierzom (formalnie majątek ten stawał się własnością Rzymian). Powołując się na źródła niejurydyczne, autorka wskazuje na niebywałe okrucieństwo cechujące wojny prowadzone przez Rzym w badanym okresie. Rzymscy dowódcy wykazywali je nie tylko wobec żołnierzy, lecz także wobec jeńców i ludności cywilnej², nie wahali się również stosować podstępów, które w świetle współczesnego prawa konfliktów zbrojnych zostałyby uznane za akty wiarołomstwa, zabronione przez to prawo (np. wysyłanie szpiegów jako parlamentarzy, pod pozorem prowadzenia negocjacji pokojowych). $\mathrm{W}$ istocie,

2 Opisy wojen i podbojów prowadzonych przez republikański Rzym dowodzą ponadto, że rzymscy legioniści niejednokrotnie wykazywali się ignorancją wobec zwyczajów wojennych przeciwnika. Tytułem przykładu, w trakcie bitwy pod Kynoskefalaj w 197 r. przed Chr., kiedy tyły wojsk macedońskich zostały zaatakowane przez rzymskich legionistów, niezdolni do obrony swoich pozycji falangici unieśli swoje sarissy w poddańczym geście, ale nierozumiejący tego gestu Rzymianie wymordowali poddających się macedońskich piechurów (zob. B.T. Carey, J.B. Allfree, J. Cairns, Wojny starożytnego świata..., s. 157). 
przytoczone przykłady podważają opinię Cycerona, według którego Rzymianie przestrzegali określonych praw podczas wojny ${ }^{3}$. Autorka znajduje jednak $\mathrm{w}$ zbadanym materiale źródłowym potwierdzenie przestrzegania norm zwyczajowych dotyczących nietykalności posłów, poszanowania neutralności państw niezaangażowanych w konflikt z Rzymem oraz zakazów niszczenia świątyń i miejsc kultu religijnego, a także respektowania postanowień zawartych rozejmów.

Rozdział III monografii - Prawo pokoju - traktuje o stosunkach, jakie łączyły Rzym z innymi państwami bądź ludami. Nie jest to jednak prawo międzynarodowe $\mathrm{w}$ dzisiejszym rozumieniu tego pojęcia, choć i w tym przypadku I. Leraczyk analizuje i ocenia instytucje prawne republikańskiego Rzymu przez pryzmat współczesnych zasad i teorii międzynarodowoprawnych. Wskazuje przy tym na wątpliwości terminologiczne dotyczące słowa „pokój” (pax), przyjmując ostatecznie, że pokój oznaczał zarówno brak działań wojennych, jak i zawarcie formalnego traktatu pokojowego. Nawiązywanie bądź istnienie pokojowych stosunków autorka łączy następnie $\mathrm{z}$ instytucjami pojawiającymi się $\mathrm{w}$ badanych przez nią źródłach - są to: amicitia (faktyczne, przyjazne relacje Rzymu z innymi państwami/ludami), foedus (wieczyste przymierze zawarte w drodze formalnej ceremonii), societas (będący wynikiem zawartego przymierza sojusz militarny Rzymu i obcego ludu) oraz hospitium (związek gościnności, odgrywający pośrednią rolę w stosunkach międzynarodowych). Co istotne, badania oparte są na wiarygodnym materiale źródłowym - autorka przedstawia szereg przykładów, które dotyczą zawierania i obowiązywania wspomnianych instytucji. Szczególną uwagę poświęca postanowieniom traktatu ustanawiającego Ligę Latyńską, przymierzom zawieranym z Kartaginą przed wojnami punickimi oraz przymierzom wskazującym na nadrzędną pozycję Rzymu (na podstawie tzw. klauzuli majestatu).

Monografię I. Leraczyk wieńczy rozdział IV poświęcony prawnym aspektom kapitulacji (deditio), rozumianej jako dobrowolne oddanie się pod władzę Rzymu bądź jako poddanie się w wyniku zakończenia działań wojennych i przegrania wojny. Autorka zwraca zatem uwagę na niejednoznaczność tej instytucji, która mogła być albo pokojowym aktem poddania się (nie był to więc rezultat wcześniej prowadzonej wojny), albo

3 Zob. S.E. Nahlik, Prawo międzynarodowe i stosunki międzynarodowe, Skrypty Uczelniane 385, z. 1, Kraków 1981, s. 36; J. Pieńkos, Prawo międzynarodowe publiczne, Kraków 2004, s. 110. 
aktem poddania się będącym skutkiem klęski poniesionej przez przeciwników Rzymian. Odnosi się również do wątpliwości dotyczących charakteru prawnego kapitulacji, w tym do opinii, że poddanie się było rodzajem traktatu. Mniej kontrowersji budzą natomiast konsekwencje kapitulacji, która prowadziła do utraty podmiotowości międzynarodowoprawnej (co przypomina współczesną instytucję bezwarunkowej kapitulacji). Autorka wyjaśnia jednak, że kapitulacja była zazwyczaj stanem przejściowym, który prowadził do zastosowania restytucji, czyli do przywrócenia poddającemu się ludowi wolności i własności, w szerszym zaś zakresie do nadania podbitemu terytorium określonego statusu względem Rzymu.

Lektura monografii "Ius belli et pacis” w republikańskim Rzymie świadczy o niebywałej erudycji autorki, która na potrzeby swoich badań sięgnęła po różnorodne źródła - jurydyczne i niejurydyczne (istotne ich fragmenty przetłumaczyła z łaciny i greki na język polski) - wykazując przy tym naukową ostrożność w ocenie zawartych w nich twierdzeń, zwłaszcza w przypadku źródeł literackich. Nie obawiała się również polemiki z poglądami innych autorów, licznymi przykładami zaczerpniętymi z materiałów źródłowych dowodząc ich słuszności bądź wskazując na pewne nieścisłości. Swoje rozważania na temat prawa wojny i pokoju prowadzi w sposób klarowny i przemyślany, każdy rozdział kończąc podsumowaniem, pomocnym przy zrozumieniu poszczególnych instytucji prawnych republikańskiego Rzymu. Wydaje się jednak, że do pełnego zrozumienia tematyki poruszonej w monografii potencjalnemu czytelnikowi przydałaby się szersza wiedza z zakresu historii starożytnego Rzymu, a zważywszy na kontekst prowadzonych badań - również z zakresu prawa międzynarodowego publicznego. Dlatego monografia prawdopodobnie zainteresuje głównie osoby specjalizujące się lub prowadzące badania naukowe we wspomnianych dziedzinach. Być może czyni to $\mathrm{z}$ "Ius belli et pacis”... pozycję skierowaną do ograniczonego kręgu odbiorców, choć tak naprawdę sięgnąć po nią powinien każdy zainteresowany historią Rzymu, wojen bądź prawa. Pozostaje mieć nadzieję, że po udanym debiucie I. Leraczyk będzie kontynuować swoje badania nad prawnymi aspektami funkcjonowania Rzymu na arenie międzynarodowej, nie tylko w okresie Republiki.

rec. Marcin Marcinko*

* Dr, Uniwersytet Jagielloński w Krakowie; ORCID ID: https:/ / orcid.org/0000-00016495-9606. 